\title{
Geometrichem Game to Improve Students' Learning Autonomy in Molecular Shape Topic
}

\author{
Sanih Gholiyah ${ }^{*}$, Achmad Lutfi ${ }^{2}$ \\ 1,2 Department of Chemistry Education, Universitas Negeri Surabaya \\ *E-mail Corresponding Author: sanih.17030194031@mhs.unesa.ac.id
}

\begin{abstract}
Learning media can help teachers to convey material to students. One of the learning media that can be used is the game. The aim of this research is to determine the feasibility of Geometrichem game as a learning medium to improve student learning autonomy in molecular shape topic according to validity, practicality, and effectiveness. Geometrichem game is expected to improve student learning autonomy. The research method applied was Research and Development: (1) preliminary study, (2) development of the product, (3) trial. The trial was conducted to 18 students of SMAN 1 Gresik. The result showed that Goemterichem game is feasible as a learning medium in molecular shape topic as (1) validity reached $89,29 \%$ or very valid, (2) practicality reached $84,03 \%$ or very practical according to response questionnaire, and $78,79 \%$ or good according to student activity observation, (3) effectiveness reached $77,78 \%$ according to classical completeness. Geometrichem game improved student learning autonomy in student motivation, the use of learning resources, self-evaluation, and environmental factor aspects, but not in learning strategy, planning, and self-monitoring aspects.
\end{abstract}

Keywords: geometrichem; learning autonomy; molecular shape

\begin{abstract}
Abstrak
Media pembelajaran dapat membantu mempermudah guru untuk menyampaikan materi kepada peserta didik. Salah satu media pembelajaran yang dapat dimanfaatkan adalah permainan. Penelitian ini bertujuan untuk mengetahui kelayakan permainan Geometrichem sebagai media pembelajaran untuk meningkatkan kemandirian belajar peserta didik pada materi Bentuk Molekul berdasarkan kriteria kevalidan, kepraktisan, dan keefektifan. Permainan Geometrichem diharapkan dapat meningktakan kemandirian belajar peserta didik. Jenis penelitian yang digunakan adalah penelitian dan pengembangan (R\&D) dengan tiga langkah, yaitu (1) studi pendahuluan, (2) pengembangan permainan, dan (3) uji coba. Permainan Geometrichem diujicobakan pada 18 peserta didik SMAN 1 Gresik. Hasil yang diperoleh menunjukkan bahwa permainan Geometrichem layak digunakan sebagai media pembelajaran untuk meningkatkan kemandirian belajar peserta didik pada materi bentuk molekul dengan rincian: (1) kevalidan mendapatkan persentase $89,29 \%$ atau sangat valid, (2) kepraktisan mendapatkan persentase $84,03 \%$ atau sangat praktis berdasarkan angket respon peserta didik, dan $78,79 \%$ atau baik berdasarkan observasi aktivitas peserta didik, (3) keefektifan mendapatkan persentase $77,78 \%$ berdasarkan ketuntasan klasikal. Permainan Geometrichem meningkatkan kemandirian belajar peserta didik pada aspek penggunaan sumber belajar, evaluasi diri, dan faktor lingkungan, tetapi tidak berpengaruh pada aspek strategi belajar, perencanaan, dan pemantauan diri.
\end{abstract}

Kata kunci: bentuk molekul; Geometrichem; kemandirian belajar; permainan 


\section{Introduction}

Education is one of the most influential sectors toward a nation's quality. Through 2013 curriculum, the government attempts to improve education quality. The 2013 curriculum aims to prepare Indonesian as individuals and citizens capable of being faithful, productive, creative, innovative, effective, and able to give a contribution to social life, the nation, and the state.

Education and Culture Ministerial Regulation of the Republic of Indonesia No. 65 of 2013 on Elementary and Middle Education Process Standards stated that the learning process in educational units is implemented interactively, inspiring, fun, challenging, motivating students to actively participate, also providing sufficient space for the initiative, creativity, and independence in accordance with talent, interest, and physical and psychological development of students. Therefore, to achieve education outcomes, chemistry learning should be conducted in a fun way so that students do not get bored and they are able to develop their abilities.

One of the goals of cultural education and national character is to develop the ability to become an independent human being. Through learning autonomy, students with their self-awareness undertake the learning activity independently. Students with learning autonomy tend to maximize their effort to get high learning achievement as they expected (Ningsih, 2016).

Learning autonomy is measured through various aspects. Among them are motivation to study, learning resource usage, learning strategy, study planning, selfmonitoring, self-evaluation in the learning process, and environmental factor (Islami, 2018).

According to the preliminary research conducted on students of grade 10 science at SMAN 1 Gresik, $88.89 \%$ of students stated they had an interest in the chemistry subject. It means that they are quite intrinsically motivated to learn chemistry. Specialized in molecular shape topic, $55.56 \%$ of students found it relatively easy. However, $72.22 \%$ of students stated that they could not do the exercise on their own without the help of others. $50 \%$ of them did not perform learning evaluation, such as correcting errors or rework the exercises given by the teacher.

The difficulties they experienced can be overcome by utilizing learning media in their learning activity. Learning media can help and ease teachers to deliver the lesson to their students. One of the learning media that can be utilized is games. Games have the potential to be useful tools for learning (Welbers et al., 2019). Games as a learning medium can help students to be autonomic learners who are able to study independently. Also, games conduct a recreational atmosphere that can reduce students' stress and increase students' learning motivation. Through educational games, students are no longer passive knowledge receivers. They will achieve meaningful learning because they are active knowledge constructors (Huang, 2019). The feedback contained in a game will increase student engagement in the learning process. Through games, students will not feel burdened while learning chemistry. Students find it a motivating and enjoyable activity (Welbers et al., 2019). There are still very few teaching materials designed to stimulate the development of students' critical and creative thinking skills in constructing their knowledge independently (Sofiana \& Wibowo, 2019).

Based on the interviews conducted with chemistry teachers in the preliminary study, chemistry learning, especially molecular shape topic, is easier to deliver by utilizing learning media. The learning media used so far is conventional media, such as Molymod model and simple objects in the surrounding. The teacher utilizes ICTlearning media in molecular shape learning activity only for presenting slides and videos to students. According to the preliminary study questionnaire given to the students, $94,44 \%$ of students wanted to learn molecular shape topic utilized by the computer-based game as the learning media. $100 \%$ of students agreed that teachers need to develop a game as learning media to ease 
their understanding of molecular shape topic.

Therefore, the game as learning media for molecular geometry chapter featured with text, music, that is fun and adventurous, utilizes computer technology that gains students' interest and learning autonomy is needed to be developed. According to the author's study, games with those descriptions do not exist, so they should be developed. Based on the background explained, the authors developed Geometrichem game, a computerbased game in molecular shape topic. This research aimed to determine the feasibility of Geometrichem game as a learning media in molecular shape topic in terms of validity, practicality, and effectiveness. The utilization of Geometrichem game in the learning activity was expected to improve students' learning autonomy.

\section{Research Method}

The research method conducted in this game development was Research and Development (R\&D). R\&D method is carried out to create a particular product and test its effectiveness (Sugiyono, 2017). The method carried out was R\&D by Sukmadinata, which consists of three stages: 1) Preliminary study, 2) Development of the product, and 3) Trial (Sukmadinata, 2016). In this research, the research method used was only conducted until a limited trial. Each stage of research and development can be described as follows.

\section{Preliminary study}

The preliminary study is the first step for development preparation. This stage consisted of three steps: literature study, field survey, and preparation of the product draft. These three steps were carried out continuously.

a. Literature study

Concepts or theories related to games that would be developed were studied especially about the characteristics of students and previous researches regarding the learning media that would be developed. b. Field study
Data pertaining to the planning and implementation of chemistry learning, especially in molecular shape topic were collected in this step. In the field study, a questionnaire of preliminary study was distributed to 18 students of grade 10 science at SMAN 1 Gresik, and an interview with chemistry teachers was conducted. The questionnaire and the interview content were perception, motivation, and teachers' skill to develop learning media for molecular shape topic, factors affecting learning activity such as learning media, learning resources, and students' learning autonomy. The interview result supported the results of the preliminary study questionnaire that had been given to the students. The results obtained were used as the background of the development of Geometrichem game.

c. Game planning

Geometrichem game was designed in the form of a storyboard to be developed next.

2. Development of the product

a. Preparation of the product draft

The storyboard obtained from the game planning step was then compiled into the initial draft of Geometrichem game.

b. Game review

The initial game was reviewed by the experts of material, learning, and media. The experts were two chemistry lecturers and one chemistry teacher. The game review step aimed to acquire suggestions and feedback for the improvement of Geometrichem game. c. Game revision

Geoemtrichem game was getting revised according to the result of the game review from the experts.

d. Game validation

The validity of Geometrichem game as a learning medium for molecular shape topic was determined by game validation. The validation process was conducted by three experts of material, learning, and media mentioned above. The validation involved content and construct validity. Content validity represents the correctness of the molecular shape concept and the appropriateness of the topic to the learning outcomes and indicators. Construct validity represents several aspects that encourage 
developing specific skills, suitability with students' characteristics, having rules, guiding students, having requirements, obstacles, and strategy in playing, challenging and actively engaging students, having success standards, giving feedback, having the aspect of decision-making, game display as learning media, audiovisual communication, and engineering aspects of the software. The validity was measured by Likert 5 rating scale. The result of the game validity was calculated as follows.

$$
\% \text { Validity }=\frac{\text { the number of scores obtained }}{\text { criterion score }} \times 100 \%
$$

Criterion score $=$ highest score $\mathrm{x}$ number of validators.

Geometrichem game is valid if it reaches $\geq 61 \%$ validity percentage or is in the valid or highly valid category (Riduwan, 2015).

3. Trial

The feasibility of Geometrichem game was measured through the game trial. In the trial stage, which had discovered students' learning outcomes, the result of the students' response questionnaire, the result of students' learning autonomy questionnaire, and the result of students' activity observation. The effectiveness of Geometrichem game as a learning media for molecular shape topic was determined by students learning outcomes. The practicality of Geometrichem game as learning media for molecular shape topic was determined by the results of the students' response questionnaire and their activity observation. The effect of Geometrichem game to students learning autonomy was determined by the result of student learning autonomy questionnaire.

This research was carried out until a limited trial conducted on 18 students of grade 10 science at SMAN 1 Gresik. The trial conducted was "One Group Pretest-Posttest Design". This research is carried out to a group that is given pretest before treatment and posttest after the treatment (Sugiyono, 2017). This design can be described as follows.

Normality test was conducted in advance to identify the normality of data distribution. Through SPSS, the normality test was carried out by Shapiro-Wilk Test as the sample size is less than 50. If the significant value is $>0,05$, the data is normally distributed. Statistical analysis of parametric statistic model conducted in this research was Paired Samples T-Test (Mishra, Pandey \& Singh, 2019; Razali \& Yap, 2014). If the $t$ statistic is $>t$ table, or the significance value is $\leq 0,05$, it is stated that there is a significant difference between students' pretest and posttest scores. Geometrichem game is effective if student outcomes improved, as evidenced by Paired Samples TTest on the pretest and posttest results.

The percentage of classical completeness was used to determine the effectiveness of Geometrichem game classically. Classical completeness was calculated using the formula.

Classical completeness $(\%)=\frac{\text { number of students who completed }}{\text { number of students }} \times 100 \%$

The game is effective if the percentage of classical completeness reaches 75\% (Kurniasih, 2019).

Geometrichem game's practicality was measured through a response questionnaire by Likert 4 rating scale and student activity observation measured by Guttman scale. The result of the game practicality from the response questionnaire was calculated as follows.

$\%$ Practicality $=\frac{\text { the number of score each indicator }}{\text { the maximum number of scores }} \times 100 \%$

The Guttman scale for student activity observation is described as follows.

Table 1

Guttman Scale Score for Student Activity Observation

\begin{tabular}{ccc}
\hline Answer & $\begin{array}{c}\text { The score for a positive } \\
\text { statement }\end{array}$ & $\begin{array}{c}\text { The score for a negative } \\
\text { statement }\end{array}$ \\
\hline Yes & 1 & 0 \\
No & 0 & 1 \\
\hline
\end{tabular}


The result of the game practicality from student activity observation was calculated as follows.

$$
\% \text { Practicality }=\frac{\text { the number of score each indicator }}{\text { the maximum number of scores }} \times 100 \%
$$

Geometrichem game is practical if the percentage of students' responses and activity observation reach $\geq 50 \%$ or is in the practical or highly practical category (Riduwan, 2015).

The effectiveness of Geometrichem game in increasing students learning autonomy was determined by the result of the learning autonomy questionnaire before and after using Geometrichem game as learning media. The questionnaire for students' learning autonomy was analyzed using descriptive statistics in the form of mode calculations, which is the most common phenomenon.

\section{Results and Discussion}

The result and discussion of the development of Geometrichem game through research and development method are described as follows.

1. Preliminary study

a. Literature study

Senior high school students commonly have difficulty in understanding chemistry. Many chemical concepts are abstract, making it difficult for students to understand chemistry, so that this subject is considered a complex subject (Khulliyah \& Fadhlan, 2019).

One of the indicators that has been studied is the low learning outcomes since chemistry subject needs high thinking and reasoning skills. While studying molecular shape topic, students feel bored because they only learn it through books and the teacher's explanation (Supriono \& Rozi, 2018).

Student-centered learning will be optimal if students have learning autonomy (Sandi, 2012). Learning autonomy is the ability of students to supervise and manage their own learning activities (Merç, 2015). Motivation, organizing and planning, selfmanagement, self-evaluation are some of the indicators of learning autonomy (Firat, 2016;
Merç, 2015). Self-evaluation helps students to improve their learning outcomes (Andrade, 2019).

The insertion of the character can be conveyed to students directly or indirectly. Direct insertion can be in the form of direct instruction. Indirect insertion of character values can be in the form of learning material content (Aeni, 2019).

The suitable learning media will facilitate students' understanding, especially in understanding chemical concepts considered difficult and abstract by students (Sulistyani \& Nirwana, 2019).

One of the learning media that can be used is game. Game as learning media also can help students to study independently and create a recreational atmosphere. Many studies about gamification found that by motivating students through reward-based learning, such as giving compliments and scoring systems in a game, their learning skill improved and eventually gain their learning outcomes (Alomari et al., 2019).

Students' curiosity increases by the desire to finish the game. The feedback contained in a game has the potential to be useful for increasing student engagement in the learning process because it makes student feel they are improving and toward the goal (Welbers et al., 2019).

b. Field study

Field survey result from student questionnaire and interview to chemistry teacher showed that computer-based game as learning media in molecular shape topic does not exist. It is necessary to develop Geometrichem, a computer-based game as learning media in molecular shape topic that is expected to help students to improve their learning outcomes and learning autonomy. c. Preparation of product draft

The product draft was prepared on a storyboard. Materials in the form of text and videos and questions for molecular shape topic according to the learning outcomes were prepared.

The storyboard contained design, features and specifications, learning outcomes, and the gameplay of Geometrichem game. Geometrichem is a computer-based game with the theme of an 
endless run. Geometrichem consists of five menus. Those are Kompetensi, Petunjuk, Materi, Main, and Pengembang. Kompetensi contains Basic Competence and learning outcomes of molecular shape topic. Petunjuk contains player guidance and game rules. Materi contains material of molecular shape topic. Main is menu to start playing. Pengembang contains information about the developer of Geometrichem game. Players are provided with five lives at each level and are reduced each time the player falls or hits the enemy. Geometrichem game consists of three levels. Players must score at least 30 to advance to the next level. Five questions must be answered to advance to the next level. Players are given two chances to answer the same question. If players give correct answers on the first chance, they will get 10 score and can immediately continue the game. If they give incorrect answers in the first chance, they will be given material in the form of text and video about the clue to answer the question. The second chance to answer the same question is provided. Pretest and posttest are 11 multiple choices questions with different score for each question and 100 score in total.

2. Development of the product

a. Development of the game product
All components prepared in the previous stage were the materials used to create Geometrichem game. Geometrichem game was developed using Construct 2 game editor. The product was exported to .exe format which is compatible with a computer with 32-bit or 64-bit versions of Windows operation system.

\section{b. Game review}

The result of the review step was suggestions and feedback for Geometrichem game in accordance with the criteria that have been determined using the review sheet. The criteria assessed include content and construct validity. One of the review results was the suggestion to add the device specification that Geometrichem game compatible on.

c. Game revision

The suggestion and feedback obtained from the game review step were analyzed, and the revision was then conducted. The following is one of the examples of game revision after being reviewed.

Figure 2 displays Geometrichem game Petunjuk menu before being revised. The layout was a little messy and confusing. The Revision was conducted by changing it into bullet points, as appeared in Figure 3.

\section{Figure 2}

Display of Geometrichem "Petunjuk" menu before Revision

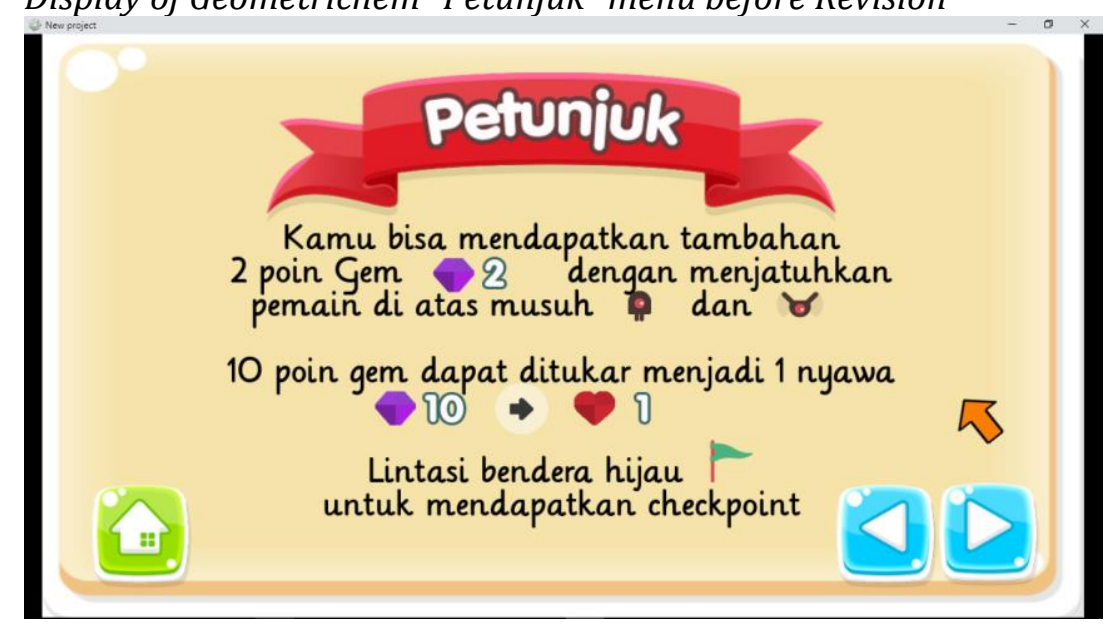




\section{Figure 3}

Display of Geometrichem "Petunjuk" Menu After Revision

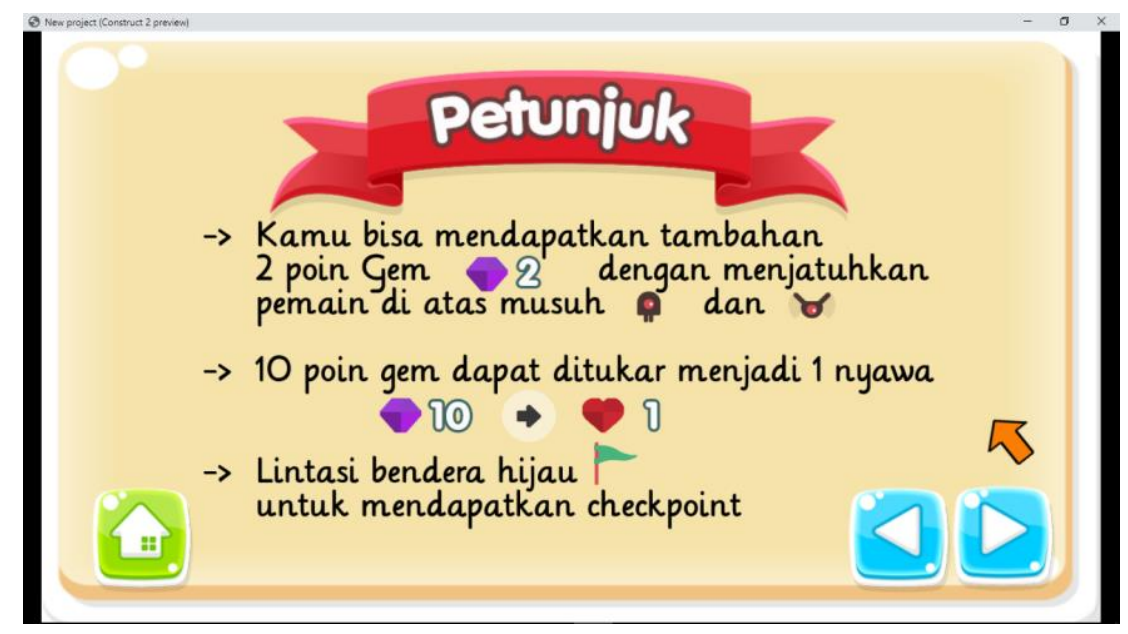

d. Game validation

Validity of Geometrichem game according to validation result by the validators is described as follows.

Table 2

Content Validity of Geometrichem Game

\begin{tabular}{clccc}
\hline No. Aspect & & Percentage (\%) & Category \\
\hline 1. & $\begin{array}{l}\text { Concept correctness } \\
\text { 2. } \begin{array}{l}\text { Appropriateness of material with learning } \\
\text { objectives }\end{array}\end{array}$ & 79.16 & 66.66 & Valid \\
\hline & & 72.91 & Valid \\
\hline
\end{tabular}

According to Table 2, the concept correctness of Geometrichem game was rated $79.16 \%$ and categorized as valid. It means that every material and question in Geometrichem game related to molecular shape topic is correct according to chemical scientific principles. The appropriateness of the topic to the learning outcomes and indicator aspect was rated $66.6 \%$ and categorized as valid. It means that material and questions in Geometrichem game are appropriate for the first stage's learning outcomes. It is suitable with the theory that an educational game must have goals according to the prepared learning objectives (Lutfi, Suyono, \& Nur, 2014). This content validity also applied to questions in the pretest and posttest that have been prepared.
According to Table 3, Geometrichem game was rated $83.33 \%$ and categorized as highly valid in the first aspect of construct validity, encouraging developing specific skills i.e. learning autonomy. By using Geometrichem game, students can perform the evaluation in studying because of the special feature of Geometrichem game which gives a second chance to answer the same question after answering questions incorrectly. Also, students are given an explanation for each question in the game. This finding is in accordance with the theory that students' learning autonomy is manifested primarily in planning, monitoring and evaluating the learning process (Jácome, 2012). Geometrichem game utilizes students to do their self-evaluation by the features provided to make them engaged in reflection 
on their learning process. Instant feedback gives a good effect to students because they Table 2

\begin{tabular}{|c|c|c|c|}
\hline No. & Aspect & Percentage (\%) & Category \\
\hline 1. & Encouraging developing a specific skill & 83.33 & Highly valid \\
\hline 2. & Conformity with the characteristics of students & 91.66 & Highly valid \\
\hline 3. & Having rules & 91.66 & Highly valid \\
\hline 4. & Having a guiding aspect & 100 & Highly valid \\
\hline 5. & Having competition, requirements, and strategies & 95.83 & Highly valid \\
\hline 6. & Challenging and actively engaging students & 83.33 & Highly valid \\
\hline 7. & Having a standard of success & 91.66 & Highly valid \\
\hline 8. & Providing feedback & 100 & Highly valid \\
\hline 9. & Having aspects of decision making & 100 & Highly valid \\
\hline 10. & Quality of display & 91.66 & Highly valid \\
\hline 11. & Audiovisual communication & 83.33 & Highly valid \\
\hline 12. & Software engineering & 91.66 & Highly valid \\
\hline \multicolumn{2}{|r|}{ Average of the validation result } & 92.01 & Highly valid \\
\hline
\end{tabular}

get what they have attempted (Welbers et al., 2019).

Geometrichem game engaged

students to participate in learning actively. Geometrichem game has been a supporting learning resource other than those provided by the teacher. Preparing learning resources is included in the planning of the learning process as a manifestation of student learning autonomy.

Geometrichem game has met the second aspect in construct validity, which is conformity with the characteristics of students, as rated $91.66 \%$ or categorized as highly valid. Geometrichem is an endless run game with molecular shape topic. Geometrichem appropriates students of senior high school who are 15 years old on average or categorized as teenagers. According to the cognitive development theory of Piagiet, the intellectual skill of teenagers reaches the formal operational stage, indicated by the logical thinking skill of abstract idea (Ahmad et al., 2016).

Geometrichem game was rated $91.66 \%$ or categorized as highly valid for having a ruling aspect. Geometrichem game has met to have a guiding aspect as it was rated $100 \%$ or categorized as highly valid. If players answer questions in Geometrichem game incorrectly, they are required to take a review on the material in the form of text or video. After that, the information about the presence of a second chance to answer the same question will be displayed. The educational game must have a guide for the players to achieve the expected goal.
Geometrichem game was rated $95.83 \%$ or categorized as highly valid for having competition, requirements, and strategies aspect, reaching $83.33 \%$ or categorized as highly valid for challenging and actively engaging students' aspect, also $91.66 \%$ for having a standard of success. There are requirements for players to proceed to the next level in Geometrichem game. To unlock the next level, the player must answer the minimum score that has been determined. To finish the game, the player must complete all three levels. There is a strategy in running the game. The player can maximize the score obtained by always answering the first chance correctly. Learners as players must face with competition, challenges, and strategies to achieve the goals and victory expected in the game (Lutfi, Suyono, \& Nur, 2014).

Geometrichem game has met the provision of feedback aspect as it was rated $100 \%$ or categorized as highly valid. When the player answers the question incorrectly, the player gets feedback in the form of video or text material to help students answer the question. When the player answers the question correctly, the player gets a score that has been determined. The explanation of the correct answer eventually displays in each question.

In having aspects of decision making, Geometrichem game was rated $100 \%$ or categorized as highly valid. The player is given five answer choices for each question. 
Geometrichem game was rated $91.66 \%$ or categorized as highly valid for quality of display aspect. The colors used in Geometrichem game are compatible. Road animations are in line with the theme of the game, which is endless run. The letter types and sizes are legible and appropriate to the game.

Geometrichem game was rated $83.33 \%$ or categorized as highly valid for audiovisual communication aspect. There is a harmony between image, back sound, and sound effects. Also, there is a harmony of the colors with the background given in the game.

Geometrichem game has met the software engineering aspect as it was rated $91.66 \%$ or categorized as highly valid. Geometrichem game as software has met the maintainable, usable, and compatible aspects. It is easy to maintain, easy to use, easy to install on the device, and does not require additional applications to operate it. Also, on the installation window, information about the specification of a computer device that is adequate for installing the program is available. Geometrichem is compatible with a computer with 32 -bit or 64 -bit versions of Windows operation system.

Geometrichem game as computerbased learning medium on molecular shape topic is declared highly valid based on expert judgment as the average of the validity percentage is $89.29 \%$.

3. Trial

Geometrichem game trial was conducted on 18 students of grade 10 science at SMAN 1 Gresik. The result of the trial stage is described as follows.

a. Student learning outcomes

Student learning outcomes were obtained from pretest and posttest results. This learning outcomes result determined the effectiveness of Geometrichem game as a learning medium for molecular shape topic. The result of the pretest and posttest is described in Figure 4.

\section{Figure 4}

Students Learning Outcomes

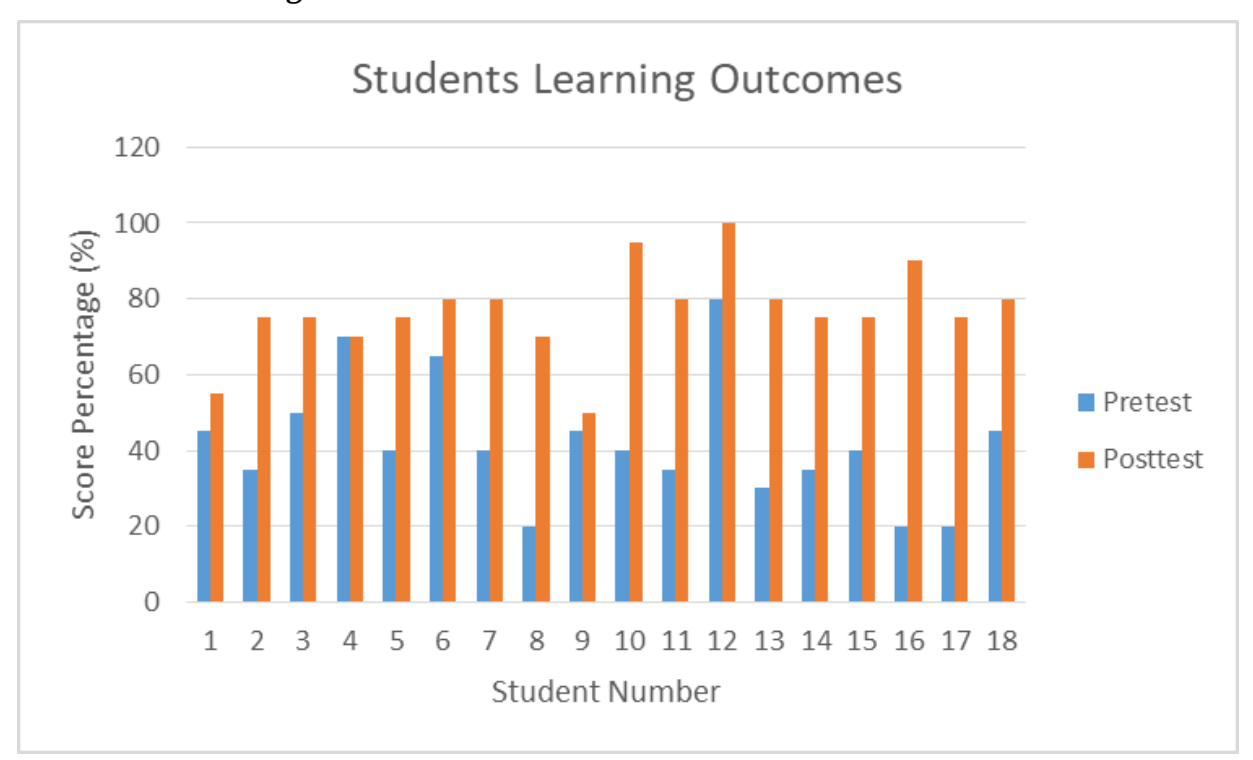

Before the learning activity was conducted using Geometrichem as learning media, a pretest was carried out to the students. The pretest results showed that 17 out of 18 students scored $<75$ or categorized as incomplete. The classical completeness determined from the pretest score was $5.56 \%$.

After using Geometrichem game as a learning medium, a posttest was carried out to the students. The posttest results showed that 14 out of 18 students scored $>75$ or categorized as complete. The classical 
completeness determined from the posttest score was $77,78 \%$, or $>75$, and Geometrichem game is effective according to the classical completeness.

The result of Shapiro-Wilk Test by SPSS was the significance value of pretest $=$ 0.084 or $>0.05$ which means the pretest data is normally distributed. The significance value of posttest $=0.074$ or $>0.05$ which means the posttest data is normally distributed. According to the normality test, it can be concluded that students learning outcome data are normally distributed. The statistical analysis used to determine the effectiveness of Geometrichem game was a parametric statistical model, in this research was the T-Test (Mishra, Pandey \& Singh, 2019; Razali \& Yap, 2014).
According, the t score $=7.762$ or $>t$ table (2.110) and the significance value $=$ 0.000 or $<0.05$. According to the result, it can be concluded that $\mathrm{H}_{0}$ was rejected and $\mathrm{H}_{\mathrm{a}}$ was accepted. It means that there is a significant difference between pretest and posttest scores. Based on the students' learning outcomes, Geometrichem game as a learning medium in the molecular shape topic is effective.

b. Result of student response questionnaire

The result of the students' response questionnaire was used to determine the practicality of Geometrichem game as a learning medium for molecular shape topic. The questionnaire was distributed to the students after Geometrichem game trial. The result of students' responses is described in Figure 5.

\section{Figure 5}

Result of Students' Response

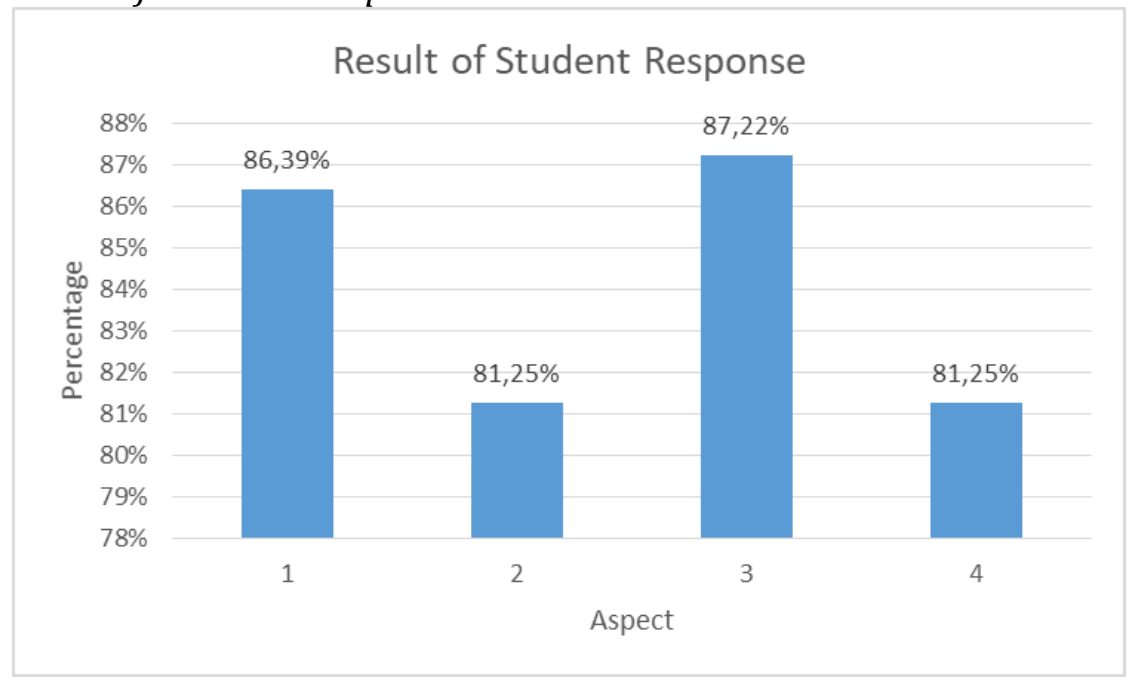

Legend:

$1=$ clarity of content and language

$2=$ convenience

$3=$ attractiveness

$4=$ usefulness

Clarity of content and language aspect was rated $86.39 \%$ or categorized as highly practical. It is supported by the results of each indicator of the aspect. The ease of understanding the material was rated $84.72 \%$. The legibility and simplicity of letters used in Geometrichem game were rated $86.11 \%$. The ease of language used was rated $86.11 \%$. Appropriateness of pictures in Geometrichem game with molecular shape topic was rated $86.11 \%$. The clarity of pictures and videos in Geometrichem game was rated $88.89 \%$.

The convenience aspect was rated $81.25 \%$ or categorized as highly practical. It is supported by the results of each indicator of the aspect. The ease of use indicator was 
rated $72.22 \%$. The ease of understanding the guidance and instruction was rated $90.28 \%$.

Attractiveness was rated $87.22 \%$ or categorized as highly practical. It is supported by the results of each indicator of the aspect. The attractiveness of the display was rated $90.28 \%$. The color selection was rated $86.11 \%$. The neatness of the design was rated $80,56 \%$. The appropriateness of layout and letters arrangement was rated $91.67 \%$. The attractiveness of the material content was rated $97.50 \%$.

Usefulness was rated $81.25 \%$ or categorized as highly practical. It is supported by the results of each indicator of the aspect. $79.17 \%$ of students stated that they were more interested in studying chemistry after using Geometrichem game, especially in molecular shape. $86.11 \%$ of students stated that by using Geometrichem game, learning activities became more fun. $81.94 \%$ of students stated that they understood molecular shape topic better after using Geometrichem game. 77.78\% of students stated that after using Geometrichem game, their learning autonomy in molecular shape topic was improved.

According to the students' responses in the overall aspects, Geometrichem game as a learning medium in molecular shape topic is categorized as highly practical as rated $84.03 \%$.

c. Results of students' learning autonomy questionnaire

The results of the students' learning autonomy questionnaire were used to determine the effectiveness of Geometrichem game as a learning medium for students learning autonomy in molecular shape topic. The questionnaire was distributed to the students twice, before and after using Geometrichem game as a learning medium in molecular shape topic. Figure 6 describes the result of student learning autonomy.

\section{Figure 6}

Students Learning Autonomy

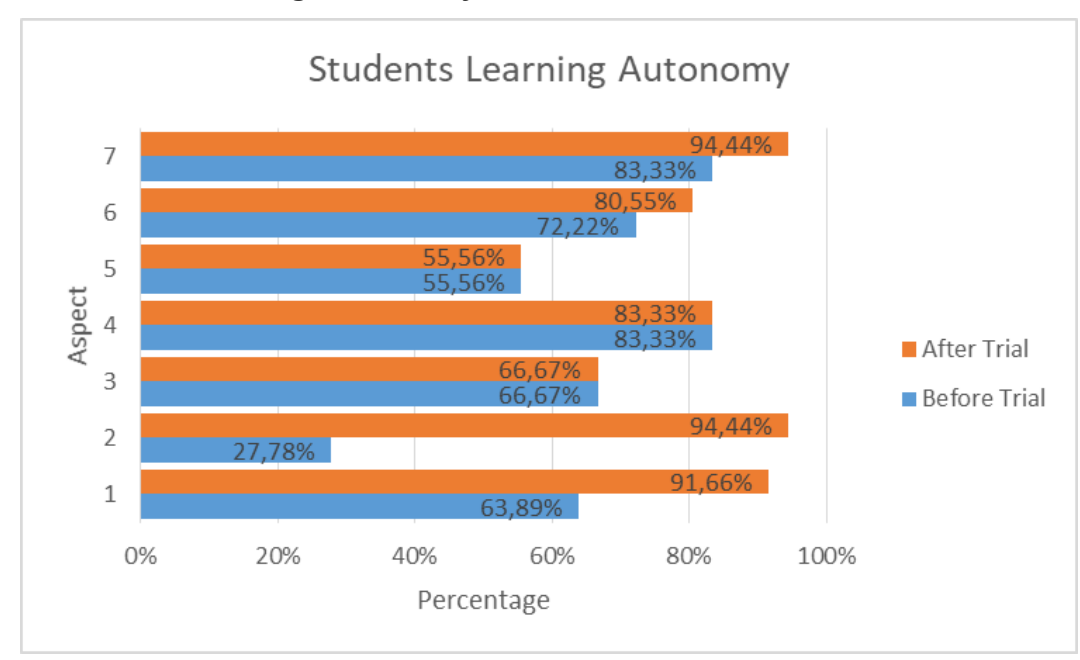

Legend:

1 = student motivation

$2=$ use of learning resource

$3=$ learning strategy

4 = planning

$5=$ self-monitoring

$6=$ self-evaluation

$7=$ environmental factor 
According to students' learning autonomy data, before the trial of Geometrichem game, $83.33 \%$ of students were motivated to learn chemistry, especially in molecular shape topic. After using Geometrichem in molecular shape topic, $94,44 \%$ of students were motivated to learn chemistry, especially in molecular shape topic. It is supported by the result of the students' learning autonomy questionnaire, which showed that before the trial, $77.78 \%$ of students stated that the learning activity carried out by the teacher could improve their learning motivation. After the trial, $88.89 \%$ of students admitted that their motivation to study was improved because of Geometrichem game as a learning medium. Before the trial, $50 \%$ of students admitted that they study chemistry, especially in molecular shape topic on their own, without being told by their parents or teacher. After the trial, $94.44 \%$ of students stated that they could study molecular shape topic independently, without being told by their parents or teacher, utilizing Geometrichem game. It can be concluded that Geometrichem game improves students' learning motivation in learning chemistry, especially in molecular shape topic.

Geometrichem game can be used as a learning resource. It is supported by the result of the students' learning autonomy questionnaire. Before the trial, $27.78 \%$ of students stated that they were not able to do their exercise without the help of others. After the trial, $94.44 \%$ of students stated that after using Geometrichem game, they were able to do their exercises without any help from others.

Geometrichem has no influence on students' learning strategy aspect, as supported by the result of the students' learning autonomy questionnaire, which showed that before the trial, $66.67 \%$ of students asked the teacher when experiencing difficulties, and the remaining $33.33 \%$ did not. The same results were found after Geometrichem game trial.

Geometrichem game does not affect the planning aspect, as supported by the result of the students' learning autonomy questionnaire, which showed that before the 78 trial, $83.33 \%$ of students prepared everything needed in learning activity such as learning resources. In comparison, the remaining $16.67 \%$ did not. The same results were found after Geometrichem game trial.

Geometrichem has no effect on the self-monitoring aspect, as supported by the result of the students' learning autonomy questionnaire, which showed that before the trial, $55.56 \%$ of students studied even though the teacher was not present. In comparison, the remaining $44.44 \%$ did not. The same results were found after Geometrichem game trial.

Geometrichem game usage improved student self-evaluation. Before the trial, $72.22 \%$ of students performed selfevaluation in molecular shape learning activity. It is supported by the result of the students' learning autonomy questionnaire, which showed that $50 \%$ of students correct their errors or rework the exercises given by the teacher before the trial. $94.44 \%$ of students always do their homework given by the teacher. After Geometrichem game trial, $80.55 \%$ of students perform their selfevaluation. It is supported by the result of the students' learning autonomy questionnaire, which showed that after using Geometrichem game, $66.67 \%$ of students correct their errors or rework the exercises as they did when playing Geometrichem. $94.44 \%$ of students always do their homework given by the teacher.

Environmental factor in this research is associated with the use of Geometrichem game as a learning medium in molecular shape topic. Before the trial, $83.33 \%$ of students agreed that if learning activity in molecular shape topic was carried out using game as a learning medium, it would improve their learning autonomy. After using Geometrichem game as a learning medium, $94.44 \%$ of students admitted that Geometrichem game improved their learning autonomy in studying molecular shape topic.

According to the students' learning autonomy in overall aspects, Geometrichem game improved student learning autonomy in molecular shape topic in student motivation, use of learning resource, selfevaluation, and environmental factor 
aspects, but not in learning strategy, planning, and self-monitoring aspects.

d. Result of student activity observation

Student activity observation

involved the installation process of Geometrichem game, the practice of playing
Geometrichem game at each level, the time needed by students to play each level, students' playing completeness, and students' learning autonomy. The result of student activity observation is described in Figure 7.

\section{Figure 7}

Student Activity Observation

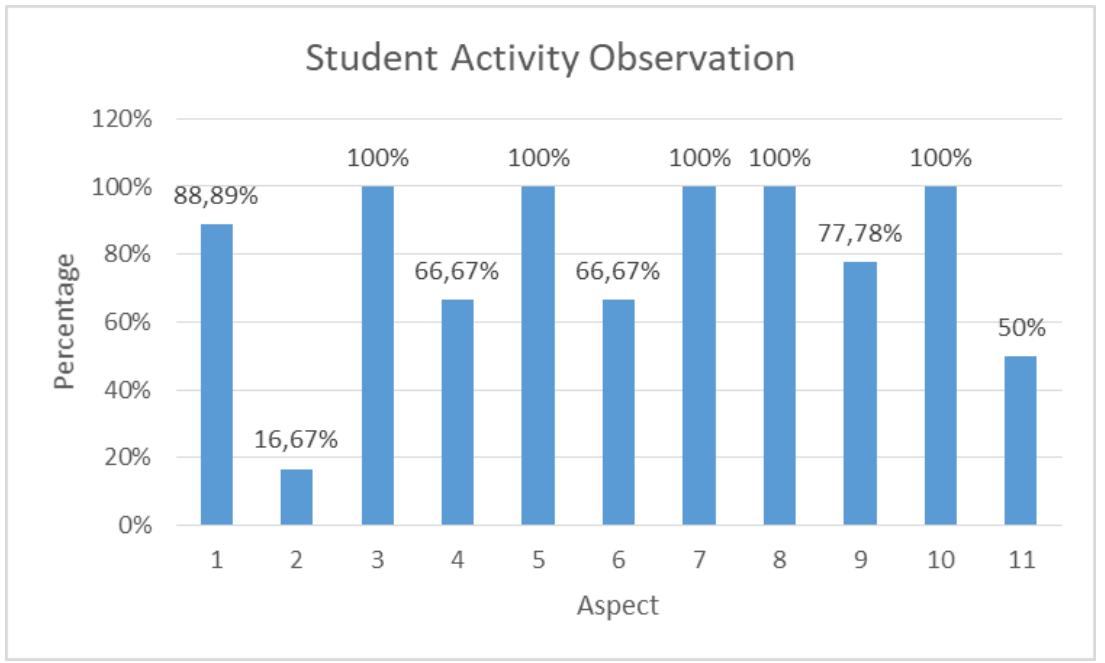

Legend:

$1=$ Have no difficulty installing Geometrichem

$2=$ Have no difficulty playing level 1

$3=$ Finish level 1 less than 45 minutes

$4=$ Have no difficulty playing level 2

$5=$ Finish level 2 less than 45 minutes

$6=$ Have no difficulty playing level 3

$7=$ Finish level 3 less than 45 minutes

$8=$ Play the game until level 3

$9=$ Repeat the game level if not reaching the minimum score

$10=$ Do the exercise by themselves

$11=$ Use books or other learning resources to help answer the question

The observation result shows that $11.11 \%$ of students had difficulty installing Geometrichem game on their computers, and the rest, $88.89 \%$ did not. The difficulty was caused by the device error and the incomplete download of Geometrichem game installer. The solution to this problem was deleting and re-downloading the Geometrichem installer, also refreshing the computer and reinstalling Geometrichem game program.
$83.33 \%$ of students had difficulty playing Geometrichem in level 1, and the rest $16.67 \%$ did not. The difficulty they had was because it was their first try. When playing level 2 and level 3, 66.67\% of students had no trouble because they had tried it at level 1.

The time needed by $100 \%$ of students to finish each level was less than 45 minutes. $100 \%$ of students played the game until level $3.77 .78 \%$ of students repeated 
the game level if they had not reached the minimum score. While the remaining $22.22 \%$ of students got less than the minimum score in level 3 and did not repeat the level. $100 \%$ of students did the exercise in Geometrichem game by themselves. 50\% of students used their books or other learning resources to help them answer questions in Geometrichem game.

The practicality percentage of student activity observation in Geometrichem game on average was rated $78.79 \%$ or categorized as good. According to the result of student activity observation, Geometrichem game as a learning medium to improve students' learning autonomy in molecular shape topic is practical.

\section{Conclusion}

Geometrichem game has been declared feasible for its usage as a learning medium in molecular shape topic with the following details. The validity of Geometrichem game in terms of content and construct validity has been rated $89.29 \%$ or categorized as highly valid by the validators. The content validity of Geometrichem game has been rated $72.91 \%$ or categorized as valid, and the construct validity has been rated $92.01 \%$ or categorized as highly valid.

The practicality of Geometrichem game according to students' responses and activity observation has been declared practical as the result of students' responses has been rated $84.03 \%$ or categorized as very good, while students activity observation has been rated $78.79 \%$ or categorized as good.

The effectiveness of Geometrichem game according to the students' learning outcomes through pretest and posttest has been declared effective as the T-test result showed that $t_{\text {score }}=7.762$ is higher than the $t_{\text {table }}=2.110$. The significance value $=0.000$ is lower than 0.05 , which can be concluded that there is a significant difference between pretest and posttest scores. Geometrichem game has been declared effective according to the classical completeness determined from the posttest score as rated $77.78 \%$.

Geometrichem game has improved student learning autonomy in molecular 80 shape topic according to the students' learning autonomy questionnaire in student motivation, the use of learning resource, selfevaluation, and environmental factor aspects, but not in learning strategy, planning, and self-monitoring aspects.

\section{References}

Aeni, N. (2019). Pengembangan Modul Bermuatan Pendidikan Karakter Materi Elektrokimia Program Keahlian Teknik Instalasi Tenaga Listrik. Journal of Educational Chemistry, 1(2), 69-81.

Ahmad, S., Hussain Ch, A., Batool, A., Sittar, K., \& Malik, M. (2016). Play and Cognitive Development: Formal Operational Perspective of Piaget's Theory. Journal of Education and Practice, 7(28), 72-79.

Alomari, I., Al-samarraie, H., \& Yousef, R. (2019). The Role of Gamification Techniques in Promoting Student Learning: A Review and Synthesis. Journal of Information Technology Education: Research, 18, 395-417.

Andrade, H. L. (2019). A Critical Review of Research on Student Self-Assessment. Front. Educ., 4(87), 1-13.

Firat, M. (2016). Measuring the e-Learning Autonomy of Distance Education Students. Open Praxis, 8(3), 191-201.

Huang, Y. (2019). Exploring Students' Acceptance of Educational Computer Games from The Perspective of Learning Strategy. Australasian Journal of Educational Technology, 35(3), 132149.

Islami, V. D. (2018). Peningkatan Kemandirian dan Prestasi Belajar Pemrograman Dasar Siswa Kelas XI TKJ Melalui Pemanfaatan Modul di SMK Negeri 1 Bantul. Undergraduate Thesis. Universitas Negeri Yogyakarta.

Jácome, É. P. (2012). Promoting Learner Autonomy Through Teacher-Student 
Partnership Assessment in an American High School: A Cycle of Action Research. PROFILE, 14(2), 145-162.

Khulliyah, \& Fadhlan, A. (2019). Penguasaan Konsep dan Retensi Melalui Pogil ( Process Oriented Guided Inquiry Learning ) Bermuatan Multiple Level Representation. Journal of Educational Chemistry, 1(1), 36-43.

Kurniasih, R. (2019). Pembelajaran Kooperatif Tipe TGT (Team Games Turnament) pada Materi Pemfaktoran untuk Meningkatkan Hasil Belajar Siswa. AKSIOMA: Jurnal Matematika Dan Pendidikan Matematika, 10(2), 261-276.

Lutfi, A., Suyono, \& Nur, M. (2014). Penilaian Permainan Bersarana Komputer Sebagai Media Pembelajaran Ilmu Pengetahuan Alam. Prosiding Seminar Nasional Kimia Organized by Jurusan Kimia FMIPA Universitas Negeri Surabaya, 20 September. Surabaya: Universitas Negeri Surabaya.

Merç, A. (2015). The Effect of a Learner Autonomy Training on The Study Habits of The First-Year ELT Students. Educational Research and Reviews, 10(4), 378-387.

Mishra, P., Pandey, C. M., \& Singh, U. (2019). Descriptive Statistics and Normality Tests for Statistical Data. Ann Card Anaesth, 22(1), 67-72.

Ningsih, R. (2016). Pengaruh Kemandirian Belajar dan Perhatian. Jurnal Formatif, 6(1), 73-84.

Razali, N. M., \& Yap, B. W. (2014). Power Comparisons of Shapiro-Wilk, Kolmogorov-Smirnov, Lilliefors and Power Comparisons of Shapiro-Wilk,
Kolmogorov-Smirnov, Lilliefors and Anderson-Darling Tests. Journal of Statistical Modeling and Analytics, 2(1), 21-33.

Riduwan. (2015). Skala Pengukuran Variabel-variabel Penelitian. Bandung: Alfabeta.

Sandi, G. (2012). Pengaruh Blended Learning terhadap Hasil Belajar Kimia Ditinjau dari Kemandirian Siswa. Jurnal Pendidikan Dan Pengajaran, 45(3), 241251.

Sofiana, \& Wibowo, T. (2019). Pengembangan Modul Kimia SocioScientific Issues (SSI) Materi Reaksi Reduksi Oksidasi. Journal of Educational Chemistry, 1(2), 92-106.

Sugiyono. (2017). Metode Penelitian Kualitatif, Kuantitatif, dan $R \& D$. Bandung: Alfabeta.

Sukmadinata, N. S. (2016). Metode Penelitian Pendidikan (11th ed.). Bandung: Remaja Rosdakarya.

Sulistyani, Y., \& Nirwana, R. R. (2019). Pengembangan Blog Pembelajaran Kimia Berbasis Contextual Teaching Learning (CTL) Materi Reaksi OksidasiReduksi. Journal of Educational Chemistry, 1(1), 44-50.

Supriono, N., \& Rozi, F. (2018). Pengembangan Media Pembelajaran Bentuk Molekul Kimia Menggunakan Augmented Reality Berbasis Android. 03(01), 53-61.

Welbers, K., Konijn, E. A., Burgers, C., Vaate, A. B. De, \& Eden, A. (2019). Gamification as a Tool for Engaging Student Learning: A Field Experiment with a Gamified App. E-Learning and Digital Media, 16(2), 92-109. 
Geometrichem Game to ... 